\title{
VIABILITY OF MOUSE OOCYTES OVULATED WITHIN 14 HOURS OF AN INJECTION OF PREGNANT MARES' SERUM GONADOTROPHIN
}

\author{
M. H. KAUFMAN AND D. G. WHITTINGHAM \\ Physiological Laboratory, Cambridge \\ (Received 16th September 1971, accepted 20th October 1971)
}

\begin{abstract}
Summary. Adult female mice ovulated within $14 \mathrm{hr}$ following an injection of PMSG. The oocytes were fertilized in vitro. Zygotes developed to the blastocyst stage when cultured for $96 \mathrm{hr}$. Transfer of two- and four-cell embryos to foster mothers resulted in viable fetuses.
\end{abstract}

Sexually mature female mice will ovulate within $24 \mathrm{hr}$ of an injection of PMSG, HCG, LH or FSH (Burdick \& Whitney, 1941; Burdick, Watson, Ciampa \& Ciampa, 1943; Saunders, 1947; Edwards \& Fowler, 1960; Stern \& Schuetz, 1970). The number of oocytes ovulated are similar to the number released at normal oestrus (Edwards \& Fowler, 1960; Kaufman, unpublished data) but unless the mice are injected immediately before oestrus, they do not mate (Stern \& Schuetz, 1970). In the present study, the viability and developmental capacity of oocytes ovulated within 13 to $14 \mathrm{hr}$ of a single injection of PMSG were examined and compared with those of oocytes obtained by superovulation, by means of fertilization in vitro, embryo culture and transfer to foster mothers.

Adult $\mathrm{F}_{1}$ hybrid mice $(\mathrm{G} 57 \mathrm{B1} \times \mathrm{A} 2 \mathrm{G}$ ), selected at random with respect to their oestrous cycles, were divided into two groups and oocytes were obtained as follows.

(1) One group of mice received an intraperitoneal (i.p.) injection of $10 \mathrm{i} . u$. PMSG (Gestyl, Organon) and oocytes were recovered 13 to $14 \mathrm{hr}$ later. Approximately $100 \%$ of the mice routinely ovulated in response to the injection (Kaufman, in preparation).

(2) Another group of mice received an i.p. injection of 10 i.u. HCG (Pregnyl, Organon) and oocytes were recovered following superovulation 13 to $14 \mathrm{hr}$ later. This group received 10 i.u. PMSG i.p. $48 \mathrm{hr}$ before administration of the HCG and the latter injection coincided with the PMSG injection of Group 1. The second group was used as the control group in each experiment since oocytes released after such treatment have previously been shown to be viable (Fowler \& Edwards, 1957; Whittingham, 1968).

Uterine spermatozoa were collected from mice (CFLP strain, Carworth Europe) mated 1 to $2 \mathrm{hr}$ previously with fertile males (CFLP strain, Carworth Europe). The females had been induced to mate synchronously by treatment with gonadotrophins (Biggers, Whitten \& Whittingham, 1971). The contents of the uterine horns were expressed into $1 \mathrm{ml}$ medium contained in an embryo- 
logical watchglass. This was diluted by the addition of a further $3 \mathrm{ml}$ medium, and droplets of approximately 30 to $50 \mu \mathrm{l}$ sperm suspension were made under liquid paraffin contained in $60-\mathrm{mm}$ diameter plastic Petri dishes (Falcon). The culture medium was the same as the modified Krebs-Ringer bicarbonate solution described for routine culture of mouse ova (Whittingham, 1971), except that the bovine serum albumin was increased from $4 \mathrm{mg} / \mathrm{ml}$ to 32 $\mathrm{mg} / \mathrm{ml}$ (Cross \& Brinster, 1970). The oviducts of the experimental groups were dissected out and the eggs from each ampulla released into separate droplets of medium containing spermatozoa by incising the dilated ampullar wall with fine watchmaker's forceps; the empty ampulla was discarded. The dishes were incubated for $5 \mathrm{hr}$ at $37^{\circ} \mathrm{C}$ in an atmosphere of $5 \% \mathrm{CO}_{2}$ in air. After incubation, the ova were washed in one change of medium $(30$ to $50 \mu \mathrm{l}$ ) containing $4 \mathrm{mg} / \mathrm{ml}$ bovine serum albumin (Whittingham, 1971, unmodified medium) to remove excess spermatozoa, and cultured in droplets of similar medium for a further 19 to $20 \mathrm{hr}$ when the number of two-cell ova was recorded.

TABLE 1

DEVELOPMENT OF MOUSE OOCXTES, FERTILIZED AND INGUBATED IN VITRO

\begin{tabular}{|c|c|c|c|c|c|}
\hline Group & Exp. no. & $\begin{array}{l}\text { No. of } \\
\text { animals }\end{array}$ & $\begin{array}{l}\text { No. of oocytes } \\
\text { cultured }\end{array}$ & $\begin{array}{c}\text { No. of two-cell } \\
\text { ova at } 24 \mathrm{hr} \\
(\%)\end{array}$ & $\begin{array}{c}\text { No. of blastocysts } \\
\text { at } 96 \text { hr (\% two-cell ova } \\
\text { developing into blastocysts) }\end{array}$ \\
\hline $\begin{array}{l}\text { Ovulated following i.p. } \\
\text { injection of PMSG alone }\end{array}$ & $\begin{array}{c}1 \\
2 \\
3 \\
\text { Total }\end{array}$ & $\begin{array}{r}5 \\
6 \\
4 \\
15\end{array}$ & $\begin{array}{r}37 \\
42 \\
43 \\
122\end{array}$ & $\begin{array}{cc}30 & (81 \cdot 1) \\
8 \dagger & (19 \cdot 1) \\
33 \ddagger & (76 \cdot 7) \\
71 \quad(58 \cdot 2)\end{array}$ & $\begin{array}{l}6^{*}(35 \cdot 3) \\
-\end{array}$ \\
\hline $\begin{array}{l}\text { Superovulated follow- } \\
\text { ing i.p. injections of } \\
\text { PMSG } 48 \mathrm{hr} \text { before HCG }\end{array}$ & $\begin{array}{c}1 \\
2 \\
3 \\
\text { Total }\end{array}$ & $\begin{array}{r}6 \\
5 \\
4 \\
15\end{array}$ & $\begin{array}{r}129 \\
107 \\
41 \\
277\end{array}$ & $\begin{array}{cc}71 & (55 \cdot 0) \\
27 \S & (25 \cdot 2) \\
29 & (70.7) \\
127 & (45.9)\end{array}$ & $\begin{array}{l}25(35 \cdot 2) \\
\overline{23}(79 \cdot 3)\end{array}$ \\
\hline
\end{tabular}

* Thirteen ova transferred at four-cell stage.

$¥$ Thirty-two ova transferred at two-cell stage.

$\dagger$ Six ova transferred at two-cell stage. $\S$ Not cultured beyond two-cell stage.

The results of the three experiments designed to compare the fertilizability and subsequent developmental capacity of oocytes obtained following PMSG injection or superovulation are presented in Table 1. In the three experiments, a total of 71 out of 122 oocytes $(58.2 \%$ ) from the groups receiving PMSG alone proceeded through the first cleavage division compared with 127 out of 277 oocytes $(45.9 \%)$ in the group undergoing superovulation. In the first experiment, there was a significantly higher proportion of two-cell ova $24 \mathrm{hr}$ after insemination, from oocytes ovulated 13 to $14 \mathrm{hr}$ after PMSG (30/37) than from oocytes produced by superovulatory treatment $(71 / 129)$. This difference did not occur in Exps 2 and 3 and, in Exp. 1, it may have resulted from the very unequal sample sizes in each group producing greater variation in the number of oocytes introduced into each culture droplet. The occurrence of fertilized ova in all droplets of medium in the groups receiving PMSG alone eliminated the possibility that only those oocytes released from animals injected in pro-oestrus were fertilizable. The two-cell embryos in Exp. 1 were cultured for a further $72 \mathrm{hr}$ 
when $6 / 17(35.3 \%)$ two-cell ova in the group receiving PMSG alone developed to the blastocyst stage (13/30 two-cell embryos had been removed for transfer to foster mothers at the four-cell stage) and 25/71 (35.2\%) two-cell ova developed to blastocysts in the group undergoing superovulation. In the same group in Exp. 3, 23/29 two-cell ova (79.3\%) developed into blastocysts.

To test the postimplantation viability and normality of the oocytes obtained following PMSG alone that had been fertilized in vitro, embryos were transferred at the two- and four-cell stages to the oviducts of suitably prepared recipient foster mothers. No superovulated oocytes fertilized in vitro were transferred in this experimental series since their viability has already been established (Whittingham, 1968). Six two-cell ova from Exp. 2 and 32 two-cell ova from Exp. 3 were transferred unilaterally to the left oviducts (5 to 7 ova/oviduct) of six pseudopregnant CFLP-strain females previously mated with vasectomized CFLP males, proven sterile, on Day 1 of pseudo-pregnancy (the day on which a copulation plug was found in the vagina) following the procedure described by Tarkowski (1959). In addition, 13 four-cell ova from Exp. 1 were transferred to the right oviducts of two CFLP mice on Day 1 of pregnancy ( 6 and 7 ova/oviduct, respectively). These females had been mated to fertile CFLP males.

On Day 15, the uterine contents of the 'pseudopregnant' group were examined. One female was found to be pregnant, and seven apparently normal fetuses were removed from the left uterine horn. Six of these had black eyes and one had pink eyes, the presence of black eyes excluding the possibility that they were native fetuses derived from a non-sterile mating. On Day 17, the uterine contents of the originally pregnant group were examined and one female was found to be pregnant. The left uterine horn contained four resorptions while the right horn (the side of egg transfer) contained one resorption, two apparently normal fetuses with black eyes and one with pink eyes. In this case, foreign fetuses with pink eyes would be indistinguishable from the native ones. These results demonstrate that oocytes released within $14 \mathrm{hr}$ of an injection of PMSG can be fertilized in vitro and are capable of further development when transferred to suitably prepared recipient foster mothers even though the animals in which this ovulation has been induced will not mate unless injected at prooestrus (Stern \& Schuetz, 1970).

The population of oocytes released within $14 \mathrm{hr}$ of an exogenous gonadotrophic stimulus may be those destined either for ovulation at the next natural oestrus or for atresia if they remain unovulated. Since the number ovulated after injecting PMSG approximates to the number released at normal oestrus, the former would probably have been ovulated naturally at the next oestrus and not become atretic.

Further studies are in progress to determine the relationship between this population of oocytes induced to ovulate by the exogenous gonadotrophic stimulus and those destined for natural ovulation or atresia.

We thank Professor C. R. Austin for his help and criticism. The work was supported by a grant from the Ford Foundation. D.G.W. is a recipient of a Beit Memorial Fellowship. M.H.K. is a recipient of an M.R.G. Junior Research Fellowship. 


\section{REFERENGES}

Biggers, J. D., Whitten, W. K. \& Whittingham, D. G. (1971) The culture of mouse embryo in vitro. In: Methods of Mammalian Embryology, pp. 86-116. Ed. J. G. Daniel, Jr. Freeman, San Francisco.

Burdick, H. O., Watson, H., Giampa, V. \& Giampa, T. (1943) A rapid test for pregnancy gonadotropins on the basis of induced ovulation in mice. Endocrinology, 33, 1.

Burdick, H. O. \& WhitNeY, R. (1941) Ovulation induced in mice by single injections of Follutein or untreated human pregnancy urine. Am. F. Physiol. 132, 405.

GRoss, P. G. \& BRINSTER, R. L. (1970) In vitro development of mouse oocytes. Biol. Reprod. 3, 298.

EDWARDs, R. G. \& FowLER, R. E. (1960) Superovulation treatment of adult mice: their subsequent natural fertility and response to further treatment. J. Endocr. 21, 147.

FowLER, R. E. \& EDWARDs, R. G. (1957) Induction of superovulation and pregnancy in mature mice by gonadotrophins. F. Endocr. 15, 374.

SAUNDERs, F. J. (1947) Induction of ovulation in the diestrous mouse by gonadotropins. Endocrinology, 40, 1.

Stern, S. \& Schurtz, A. W. (1970) Asynchrony of ovulation and mating in mice treated with gonadotrophins. F. Reprod. Fert. 23, 257.

TARKowsKi, A. K. (1959) Experiments on the transplantation of ova in mice. Acta theriol. 2, 251.

Whittingham, D. G. (1968) Fertilization of mouse eggs in vitro. Nature, Lond. 220, 592.

Whirtingham, D. G. (1971) Gulture of mouse ova. F. Reprod. Fert., Suppl. 14, 7. 